\title{
High-speed train for Australia bites the million-dollar bullet
}

\section{Sydney}

A MULTI-MILlion dollar feasibility study of a $350 \mathrm{~km}$-an-hour high-speed rail-line linking Sydney, Melbourne and Canberra was announced earlier this month by a venture company formed to conduct the project.

First indications that the project would proceed came from New South Wales Premier Barry Unsworth during a trip to Japan. Unsworth met representatives of Kumigai-gumi, a Japanese construction company with a high profile in Australia and one of the partners in the train venture. Kumigai is supplying the knowhow for a $\mathbf{A} \$ 450$-million tunnel running under the Sydney harbour. After a ride on the Bullet Train, Unsworth's enthusiasm ran away with him. He not only expressed his support for the project, but added, much to the surprise of the private companies that will pay for the new rail line, that a full-scale feasibility study would proceed.

Known as the Very Fast Train (VFT) and travelling faster than any train existing, it would cover the $876 \mathrm{~km}$ between Sydney and Melbourne in three hours. The VFT route takes it around the seaward side of the Snowy Mountains, with the exception of Canberra a fertile but sleepy rural corner of the continent. The present rail link goes inland, to the west of the mountains, missing Canberra. The trip from Sydney to Melbourne takes 12 hours.

VFT is the brainchild of Dr Paul Wild, who started his career as a radioastronomer and retired as chairman of the Commonwealth Scientific and Industrial Research Organization in 1985 . He says VFT should take five years to construct at a cost of $\mathrm{A} \$ 4,000$ million. $\mathrm{He}$ hopes to see it finished in 1995.

According to Wild, the speed of the train will be exploited to reduce construction costs. Because the kinetic energy of a body in motion increases as the square of its velocity, the very high speed of the train can be tapped to carry it over hills regardless of the gradient. This allows the use of much steeper gradients than conventional trains can cope with, perhaps up to 1 in 20 , and greatly reduces the need for massive earthworks.

The economic viability of the VFT depends on the passenger market, an issue to be explored in the first stage of the feasibility study. A A $\$ 600,000$ prefeasibility study gave very positive results, suggesting the likelihood of more than 3 million trips a year. This number would be accommodated by about 30 trains running each way daily. According to Wild, as a rule of thumb, each person living

\section{Canadian science and technology to make a happy marriage?}

Toronto

IN an attempt to bring off a happy marriage between advanced science and technology and Canadian industry, Prime Minister Brian Mulroney's government has announced the creation of a new national Department of Industry, Science and Technology. The new department will cover the entire country through three regional industrial development offices. Although the budget for the whole department has not been made public, the office in Edmonton, Alberta, will have a budget in excess of $\mathrm{C} \$ 1,000$ million.

The new department seems to have been inspired by the Japanese Ministry of International Trade and Industry. Until now, Canadian research and its main agencies, including the National Research Council, have reported to Parliament through a policy-making ministry with no real spending power or clout. The new department brings Canada into line with many other industrial nations by tying science to industry.

The department merges the present Ministry of State for Science and Tech- nology with the Department of Regional Industrial Expansion. It will be headed by Industry Minister Michel Côté with Frank Oberle, the current Science Minister, as his junior.

The new department is intended to reflect Canada's commitment to a technologically advanced industrial economy. Part of its role will be to help establish new knowledge-based industries to improve the country's long-term international competitiveness.

There is uncertainty about how the new department will work. Professor Alan Carswell of York University, a past president of the Canadian Association of Physicists and president of Toronto-based Optech Inc., does not want to judge the new department too hastily. "The words describing it are reasonable", says Carswell, but he adds that many Canadian scientists are disillusioned by cuts in research budgets. Carswell also says the government scheme to have industry provide matching funds for research has been a heavy burden for industry.

Russell McNeil along the rail catchment area makes one trip a year. Almost half of Australia's 17 million population lives in the SydneyMelbourne area.

Besides Kumigai, the other partners in the project are an Australian-based transport multinational, TNT Management, with interests in road and air transport, and Elders-IXL, a Melbourne wheelbarrow-maker which has grown into a diversified multinational.

TNT is cutting its teeth on rail transport with the construction of a monorail around Sydney's central business district which is due for completion in time for Australia's bicentennial next year.

Charles Morgan

\section{Canada and Ireland promote science ties}

\section{Dublin}

LIKE Canada, Ireland is seeking to foster closer ties between industry and its research community, as well as encouraging companies, particularly small ones, to develop research expertise. To this end, Dr Sean McCarthy, Minister for Science and Technology, has recently launched a new IR£1-million science and technology programme.

Although the ministry's programme will emphasize work in electronics and engineering - including IR£1 million for equipment to the Institute for Industrial Research Standards - there is also IR£0.6 million for the establishment of a national biotechnology programme. This money will be used to set up three centres of excellence at third-level colleges. These will be used to generate new products and processes as well as acting as sources of trained personnel for industry. The centres will focus their efforts on diagnostics, cell culturing and food technology.

The IR $\mathbf{2} .5$ million is in addition to the IR£14 million allocated in the annual budget to the various state-funded science and technology bodies. Although the additional research funding is relatively small, it is nonetheless welcome in the current climate of budgetary cutbacks. Announcing the new programme, the Taoiseach (Prime Minister) Charles Haughey undertook to make it a permanent feature of the annual budget. An expanded second phase of the biotechnology programme is already being planned for next year.

McCarthy's appointment as science and technology minister following the Fianna Fail electoral victory earlier this year marks the first time there has been a minister with specific responsibilities for science. The science and technology ministry is a junior ministry within the Department of Industry and Commerce.

Mary Mulvihill 